\title{
Federalization and Ethnoterritorial Concurrence in Spain
}

\author{
Lui s Moreno \\ Instituto de Estudios Sociales Avanzados (CSIC)
}

\begin{abstract}
The progressive federalization of the Spanish Estado de las Autonomías (State of the Autonomies) is in accordance with a model of multiple ethnoterritorial concurrence. The process of territorial accommodation in Spain relates substate ethnic mobilization with the competitive interplay among Spanish regions and nationalities in pursuit of political and economic power. The regions and nationalities also strive for the achievement of legitimation for their institutional development. This article reviews developments and features that have set this type of plural competition and solidarity into play in Spain at the turn on the millennium.
\end{abstract}

\section{Introduction}

Spain is a national state made up of nationalities and regions (Autonomous Communities) and, as such, has a pluri-ethnic composition. Article 2 of the 1978 Spanish Constitution, "...recognizes and guarantees the right to autonomy of the nationalities and regions of which it is composed, and the solidarity amongst them". The word "federal" does not appear in the provisions of the democratic Constitution adopted by popular referendum in Spain in $1978^{1}$. However, the 'quasi-federal' or 'federalizing' philosophy which inspires the Spanish constitutional text is to be underlined. Indeed, it seeks to combine both unity and diversity ${ }^{2}$.

The Estado de las Autonomías, or State of Autonomies, has greatly transcended the traditional cultural patterns of ethnic confrontation in Spain. The Spanish case can be regarded as one of progressive federalization in line with the asymmetrical nature of its internal units and which serves the purpose of accommodating their diversity and plurality. Despite its secular ethnic conflicts, Spain is an entity clearly identifiable as a historical unity. This unity goes beyond the simple aggregation of territories and peoples with no other affinity than their coexistence under the rule of one common monarch or political power. The social and cultural cohesion which makes up her unity does not, however, obliterate internal oppositions. As has happened in the past, territorial rivalries among Spanish nationalities and regions have brought about an extra cultural incentive for creativity and civilization, while still having been used as an excuse for confrontation.

Spain offers a striking example of the shortcomings of some theories of modernization, namely diffusionist functionalism. According to such a paradigm the diffusion of cultural and social structural values, together with modernization and economic development, should provoke

\footnotetext{
${ }^{1}$ 1. On December 6th, 1978, the Spanish Constitution received $87.9 \%$ "Yes" votes, $7.8 \%$ "No" votes, and $4.3 \%$ null or blank votes. Abstention reached $32.9 \%$ of the registered electorate.

2 2. Daniel J. Elazar, Exploring Federalism (Tuscaloosa: University of Alabama Press, 1987), and "From Statism to Federalism: A Paradigm Shift", Publius: The Journal of Federalism 25:2 (Spring 1995): 5-18.
} 
progressive cultural, political and economic integration thus replacing territorial cleavages with a set of functional and economic conflicts, primarily class conflict. In the case of Spain, the persistence of a dual identity or compound nationality shows the ambivalent nature of the internal ethnoterritorial relations that have existed within Spain in recent times. Dual identity concerns the way in which citizens identify themselves in sub-state regions. It incorporates --in variable proportions, individually or subjectively asserted-- the local/ethnoterritorial ascriptive identity and the state/national identity produced by national integration -or rather, malintegration- in the process of state building ${ }^{3}$.

Spain's territorial unity has been put under strain by the centrifugal action of its ethnic and linguistic diversity, as well as by that of either weak state institutions or violent central rule. Moreover, there has been a traditional lack of congruence or a 'noncongruence', so to speak, between political and economic powers. Catalonia and the Basque Country, the two Northern peripheral Spanish communities with full ethnic/cultural potential, have remained as two of the three economically most dynamic territories of Spain, the third being the region of Madrid. This non-congruence has traditionally nourished the centrifugal tendencies present in modern Spanish history, tendencies which found expression in a number of armed conflicts: the Revolt of the Reapers, 1640-1652; the War of the Spanish Succession, 1701-1714; the Carlist wars, 1833-1840, 1846-1848 and 1872-1875; the Tragic Week of Barcelona, 1909 and, finally, the Civil War, 1936-1939.

The current process of federalization in Spain will involve a long process of power delimitation in its three-tier system of government (local, intermediate and central) before its federal-like arrangements take shape within the European Union. Once this situation has been achieved, a constitutional revision should functionally incorporate these divisions of powers thus avoiding the great political difficulties which would have occurred had the process developed inversely.

\section{Francoism and national unity}

Catalonia, the Basque Country, and Galicia had initiated autonomist processes in the context of the Second Republic by the time of the military coup led by General Franco in July of 1936. Other regions had not yet taken the legal steps required by the Constitution but had shown their willingness to do so. Among these Aragon, Andalusia, Asturias, the Balearic Islands, the Canary Islands, both Castiles, Leon, and Valencia can be cited. Thus, the autonomist process, though incipient, was spreading throughout 3 Spain by the time the Civil War broke out. With the victory of Franco's forces, a long period of political centralization ensued, aiming once again to create a uniform Spain.

Two of the most notable pathological fixations of the Franco dictatorship (1939-75) were anticommunism and anti-separatism. On the one hand, communism, combined with an unfounded and paranoid supposed judaeo-masonic conspiracy, threatened the conception of Spain as an imperial power, and the Western Christian civilization as a whole. On the other, the "sacred unity of the homeland" was regarded as an indispensable unifying element and raison d'être of General Franco's despotic regime. To a large extent, Francoism justified itself through its ability to suppress and extirpate all forms of autonomism, regionalism and culturally different

\footnotetext{
${ }^{3}$ 3. See, e.g., Juan Linz, "Politics in a Multi-Lingual Society with a Dominant World Language: The Case of Spain", Les états multilingues: problems et solutions, eds. J.G. Savard and R. Vigneault (Québec: Les Presses de l'Université Laval, 1975), pp. 367-444; and Luis Moreno, "Ethnoterritorial Concurrence and Imperfect Federalism in Spain", Evaluating Federal Systems, ed. B. de Villiers (Cape Town: Juta, 1994).
} 
ethnoterritorial movements. Any form of federalism or wish for self-government was understood by the Franco regime as 'separatism'.

The Francoist conception of national unity, at the expense of the cultural and ethnic variety of the people of Spain, degenerated into an obsessive dogma which became central to the ideology of the reactionary coalition which dominated the country uninterruptedly from 1939 to 1976. In fact, the linguistic and cultural oppression of Francoism stimulated regional autonomism and ethnic nationalism in Spain. This oppression consisted in the obliteration of cultural differences the mere existence of which appeared to question the Francoist conception of Spain. Of course, these differences did not only question this conception, but constitute clear evidence that the conception was erroneous. In spite or because of this misconception, Franco set up a program of 'national' homogenization.

For Francoist supporters 'eternal Spain' was the ideological expression of an old and unpolluted 'Castilian spirit' with a universal language and ideals beyond the limits of time and space --a Spain, in short, which had emerged victorious and misunderstood in the midst of a turbulent era for humankind. Francoism regarded Spanish ethnoterritorial peculiarities as quaint signs of the unique Spanish 'soul'. Any deviation from this Spanish Volkgeist was not only illegitimate but also dangerous and punishable. The ethnoterritorial reality was, however, very different from such a view.

Throughout its long political life (1939-75), Francoism nonetheless failed to achieve its aim of eliminating Spain's internal ethnic differences. In fact, it achieved exactly the opposite: the results flatly contradicted what the governing classes sought ${ }^{4}$. They had advocated a peculiar and artificial idea of Spanish nationalism which had little to do with the historical process of state construction in Spain, and which made centralism and dictatorship concomitant concepts. But it was actually the case that Francoism supported Spanish nationalist values based on sectarianism and exclusion, bringing about a 'de-naturalization' of ethnoterritorial relations in the country. The result of this was that by the beginning of the democratic transition in the 1970s, the very concept of anything Spanish was regarded by the democratic and progressive forces as synonymous with repression, cultural hegemonic imposition and fear of Spain's plural reality.

From the 1960s onward, Francoism reinforced its assimilationist policies through the use of television and modern mass media. This was carried out in spite of the fact that the multilingual character of Spain automatically worked against the viability of the imposition of a single language. Thus, a platform for popular grievances began to grow, though to very different degrees. Regions and counties which had previously shown only weak signs of autonomism or regionalism found their reasons to claim these rights by the end of the 1970s. From the Canaries to the Balearics, from Asturias to Extremadura, the regions of Spain discovered the attractions of local identity.

\section{Regional autonomism and ethnic nationalism after Franco}

The autonomist boom owed much of its emergence to the nature of Francoism. During the final years of its existence, the opposition to the regime developed a compact program for democratic rights and for the political decentralization of the Spanish state. In the so-called

\footnotetext{
${ }^{4}$ 4. Salvador Giner, "Ethnic Nationalism, Centre and Periphery in Spain", Spain: Conditional Democracy, eds. C. Abel and N. Torrents (London: Croom Helm), pp. 78-99.
} 
'historical nationalities' in particular (Catalonia, Galicia and the Basque Country), the forces opposed to Francoism were able to articulate a highly coherent political discourse denouncing the absence of democracy and the continuous official attacks on their identities. In these communities, democratic and ethnoterritorial vindication became analogous. Every time that Basque and Catalan opposition groups negotiated secretly in exile with other democratic forces, the demand for one thing was invariably tied to the assertion of the other. In this way the ideology of autonomism and political decentralization made its way into Spanish democratic political consciousness. Francoism, therefore, provided the atmosphere necessary for today's minority regionalism, autonomism, and nationalism.

Although it remains true that, strictly speaking, separatism and federalism have older roots. The ability of peripheral nationalism to overcome ideological and political divisions manifested itself in cases of substantial consensus among the forces opposing the Franco regime. The most emblematic may be the Assamblea de Catalunya, founded in 1971. It was highly representative of Catalan society in the 1970s. Its ability to create a democratically legitimate alternative to the Franco regime in Catalonia constituted a unique precedent for the peaceful transition to liberal democracy the whole country was later to enjoy.

In the Basque Country, the separatist guerrilla group ETA found considerable popular support, and given the oppressive political circumstances, it became intertwined with the democratic movement. In 1973, ETA assassinated Admiral Carrero Blanco, Franco's Prime Minister, appointed by the dictator to become his political heir. It is worth noting that those who then advocated political violence against the Franco dictatorship were not regarded without sympathy by many sectors of the population, and not only in the Basque country. With the advent of liberal democracy, many of these people would eventually distance themselves from ETA and the paradoxical intensification of its actions. The military nucleus of ETA continued to insist that the militants of the Basque national liberation movement were the only victims of police torturers and of the representatives of centralist oppression ${ }^{5}$.

After Franco's death in 1975, the transitional process to democracy began in earnest. The democratic parties did not have a clear-cut model for the type of decentralized state they broadly advocated. However, the majority wanted home rule for all the Spanish nationalities and regions. The constitutional expression of such a strong platform constituted a major political challenge, for Spanish modern history had witnessed tragic failures where ethnicity and the territorial sharing of power were concerned.

The broad party-political consensus which made the drawing up of the 1978 Constitution possible, also brought with it an element of ambiguity in the formulation of the territorial organization of the Spanish State. In fact, two different conceptions of Spain, which had traditionally confronted each other, were formulated. Subsequently, a middle way was negotiated and explicitly recognized by the Constitution: on the one hand, the idea of an indivisible and solely Spanish nation-state, on the other, a concept of Spain as an ensemble of diverse peoples, historic nations and regions.

The text of the 1978 Constitution reflects many of the tensions and political dilemmas which existed in the discussion of such territorial provisions. However, it also reflects a widespread

\footnotetext{
${ }^{5}$ 5. Francisco Letamendía, "On Nationalisms in Situations of Conflict: Reflections from the Basque Case", Nationalism in Europe. Past and Present, (Vol. I), eds., J.R. Beramendi, J.R. et al (Santiago: Universidad de Santiago de Compostela, 1994), pp. 247-275.
} 
desire to reach political agreement among all the constituent political parties which were involved in the process of negotiation. An open model of decentralization was the consequent result for the territorial organization of democratic Spain.

\section{Development and consolidation of the State of the Autonomies}

Title VIII of the 1978 Spanish Constitution made it possible for one, three, all or none of the Autonomous Communities to be self-governing. It depended on the political will expressed by the inhabitants of each nationality or region, or by their political representatives. It also made it possible for the degree of self-government to be wide or restricted according to the wishes of the nationalities and regions: "Title VIII [of the Constitution] allows Spain an autonomy, or three, or a few, or all, or none, according to the will expressed by the people or the representatives of a given territory, and allows that autonomy to be wide or restricted, and that different communities should have the same or different degrees of autonomy, and that they organize themselves homogeneously or heterogeneously, and for the mistakes made in the process to be rectified" 6

Conservatives, Centrists, Nationalists, Socialists and Communists hammered out an agreement of a type of 'quasi' or 'asymmetrical' federalism which would not jeopardize the constitutional consensus on the issue of decentralization, the most delicate to be agreed upon in the period after the demise of Francoism (1975-78). Hence, the accepted solution took the form of an unwritten pledge to extend the procedures of political transaction and consociationalism into the future. ${ }^{7}$ As we have seen above, this open model of asymmetrical federalism did not presuppose the ways and means by which the different spatial entities could finally be articulated. Thus, an implicit desire was expressed by the 'Fathers' of the 1978 Constitution to provide the procedures and degrees of self-government to be pursued by the nationalities and regions while allowing them a high degree of flexibility. The formulation of a clear division of powers based upon 'orthodox' federal techniques was, however, avoided.

The arbitrating role of the Tribunal Constitucional, the highest court in Spain, has been of paramount importance for the subsequent implementation of the Estado de las Autonomías. It has amongst its attributes the capacity to decide in legal conflicts between the state (central government) and the Autonomous Communities, or even in conflicts among the latter. According to the 1978 Constitution there is a need for compromise on the nomination of candidates to the Constitutional Court. ${ }^{8}$ This circumstance provides the highest Court with a great deal of authority and independence.

\footnotetext{
${ }^{6}$ Jaime García Añoveros, "Autonomías, un proceso abierto", El País (29/30/31 May 1984).

${ }^{7}$ See, e.g., César Díaz López, "Centre-Periphery Structures in Spain: From Historical Conflict to Territorial Consociational Accommodation?", Centre-Peripheral Relations in Western Europe, eds. Y. Meny and V. Wright (London: Allen \& Unwin), pp 236-272; and Juan Linz, "Spanish Democracy and the 'Estado de las Autonomías'", Forging Unity Out of Diversity: The Approaches of Eight Nations, eds. R.A. Goldwin, A. Kaufman and W.A. Schambra (Washington, D.C.: American Enterprise Institute for Policy Research), pp. 260-303.

${ }^{8}$ Due to the Spanish system of proportional representation (D'Hont rule on provincial constituencies for the election of the MPs to the Chamber of Deputies or Lower House), it is highly unlikely that a single political party could ever achieve the required three-fifths of the total members of both Houses of Parliament.
} 
Some critics have pointed out that the role of the Constitutional Court in solving disputes relating to governmental powers places electoral bodies in a position which is subordinate to the judiciary. Consequently, they argue, there is a risk that judges may become political and that their known political views are taken into account when they are appointed. However, the need for a pact between government and opposition in the election of the members of the Tribunal Constitucional has so far proved to be a barrier against open political sectarianism in the nomination of the candidates. For instance, the important judgement of the Court (August 5th, 1983) on the LOAPA Act (Organic Law on the Harmonisation of the Autonomy Process) passed by the Spanish Parliament, reinforced the open and federal-like interpretation of the 1978 Constitution very much against the views of center-right UCD and Centre-left PSOE Governments in the early 1980 s.

In the general process of decentralization during the 1980s the case of the southern region of Andalusia is of particular relevance and deserves closer, although brief, attention. In 1982, political leaders and the population at large in Andalusia opted for the same 'fast route' procedure and degree of home rule previously pursued by the three so-called historical nationalities: Catalonia, the Basque Country and Galicia. The result of the popular referendum held in Andalusia ratified these wishes and, furthermore, such a 'demonstration effect' sparked off a sense of ethnic competition for other regions in pursuit of equal access to home rule. This development brought about a crucial element of heterogeneity which modified the model, implicitly accepted by some Catalan and Basque nationalists, of implementing only home rule in the Spanish historical nationalities while the rest of the regions would merely be granted administrative decentralization (de-concentration).

The decentralization process embodied in the 1978 Spanish Constitution has undergone a long period of consolidation. Support for autonomy, apart from the Basque and Catalan communities, has been particularly strong in Andalusia and other regions (the Canary Islands, Galicia and Valencia). Certainly, it is the case that some regions were 'encouraged' by their most prominent political parties to enter into the autonomist process. Some areas with no self-governing tradition whatsoever were suddenly inspired to claim autonomic rights. These were mainly uniprovincial communities lacking ethnoterritorial specificity, unless they recognized their origins elsewhere, such as the cases of Cantabria, La Rioja, and even the province of Madrid. In some cases, the decentralization process has entailed a break-off from the ethnoterritorial base of certain provinces. One of the consequences of this has been the creation of hybrids such as Castile-La Mancha or Castile and Leon.

The cases of Navarre and the Països Catalans ${ }^{9}$, have exemplified the difficulties in setting clear boundaries in certain regions. For radical Basque separatists, Navarre is an integral part of their country which can never be given up ${ }^{10}$. For most of the people of Navarre, however, the old kingdom has more than enough right to its own constitution as a fuero. The Catalan Countries are perceived as a whole with a composite identity deserving political treatment as such by not just pan-Catalanist parties, but by the usually more cautious President of the Catalan Government, Jordi Pujol, in his federalist understanding of Spain: "In the specific case

\footnotetext{
9 . "Catalan Countries". Expression used by some to denote the Principate of Catalonia, the Kingdom of Valencia, and the Balearic Islands. Frequently included is Rosselló (Roussillon), in southern France, where Catalan is spoken.

10 This is the claim made by both Herri Batasuna, the political branch of ETA, the Basque terroristseparatists, and ETA itself.
} 
of Spain I could conceivably be a federalist, if the federation was based on genuine and authentic nationalities of the state, viz. Euskadi [Basque Country], Galicia, the whole of Castile, and the Catalan Countries (or just Catalonia, if Valencia and the [Balearic] Islands ... rejected being associated with the Principate [of Catalonia])." ${ }^{11}$ While for some communities autonomy meant the greatest possible degree of self-government and the narrowest possible gap between the people and power, for others it entailed a greater emphasis on support from the central administration against unemployment, underdevelopment, or outright poverty. A certain dichotomy has thus arisen between the political perception of the exercise of selfgovernment and the understanding of the concept of solidarity with the aim of achieving greater equality. In general terms, it can be said that the decentralization process has been assimilated by most Spaniards. This reality legitimates its political expression. However, although far from over, the decentralization process needs to gradually adapt to new forms of inter-governmental relations, especially at the level of institutional collaboration. According to 1990 data, most Spaniards considered that relations between autonomous governments and central government should be "collaborative" (80.7\%) and involving "shared responsibilities" $(50.2 \%)^{12}$. The articulation of institutional relations involving shared powers and responsibilities lies at the very base of the federal-like ethnoterritorial relations of Spain. 9. "Catalan Countries". Expression used by some to denote the Principate of Catalonia, the Kingdom of Valencia, and the Balearic Islands. Frequently included is Rosselló (Roussillon), in southern France, where Catalan is spoken.

\section{Multiple ethnoterritorial concurrence}

The level of territorial and political reorganization attained after the democratic transition, and the gradual establishment of the Estado de las Autonomías, has generated a complex of relations in Spain which we may call multiple ethnoterritorial concurrence ${ }^{13}$. Their constitutive features involve a dynamic of political, social and economic elements, and set the scene for both conflict and co-operation in Spain. The use of the term concurrence is meant to be understood as multiple and simultaneous competition which results in broad political agreements, though these do not arise necessarily, nor as a result of a lineal process. Underlying this semantic interpretation there are chiefly elements of asymmetry, heterogeneity and plurality. Taken together they constitute the federal-like territorial organization of the Estado de las Autonomías.

To give a clear structure to our present concern, it is worth adopting a sequential categorization for multiple ethnoterritorial concurrence. In the first place two axioms may be identified which are of special relevance to the Spanish case, although they are generally applicable to most of the contemporary world's decentralized and federal systems. They are (a) conflicting intergovernmental relations, and (b) the politicizing of ethnoterritorial institutions. Secondly, two premises are considered in relation to the stage prior to the development of the Estado de las Autonomías. These are (c) the differential fact, and (d) centralist inertia. Thirdly, there are three principles analyzed as fundamental pillars upon

\footnotetext{
11 Jordi Pujol, Construir Catalunya (Barcelona: Pòrtic, 1980), p. 26

12 Manuel García Ferrando, Eduardo López-Aranguren and Miguel Beltrán, La conciencia nacional y regional en la España de las Autonomías (Madrid: Centro de Investigaciones Sociológicas, 1994), p. 113.

${ }^{13}$ Luis Moreno, "Multiple Ethnoterritorial Concurrence", Nationalism and Ethnic Politics 1 (Spring 1995): 11-32; Luis Moreno, "Ethnoterritorial Concurrence and Imperfect Federalism in Spain", Evaluating Federal Systems, ed., B. de Villiers (Cape Town: Juta, 1994), pp. 170-1.
} 
which the organizational rationale of the 1978 Constitution rests, explicitly or implicitly: (e) democratic decentralization, (f) comparative grievance, and (g) inter-territorial solidarity. Lastly, there are three rules which are taken to be determining factors in the progressive federalization which the unfinished decentralization process in Spain entails: (h) centrifugal pressure, (i) ethnoterritorial mimesis, and (j) the inductive allocation of powers.

We shall now consider briefly each of these elements in turn. The basis of future developments in political ethnoterritorial relations in Spain lies in their agile and fluid nature.

\section{Axioms: Conflicting Intergovernmental Relations, Politicizing Institutions}

(a) The axiom of conflicting intergovernmental relations is associated with the political leanings and party-political affiliations present at all levels of government and institutions representing territorial interests. It involves conflict and consensus analogous to that which can be found in any other country with a similar territorial organization. In many respects, it also provides a testing ground for Spain's democracy. It must be said that since 1980 criticisms of the degree of dispersion and fragmentation of political life have flourished in Spain. Some have proposed new forms of centralization as 'solutions' to what is considered an 'unbearable' situation. Such criticisms come from those who feel threatened by a sense of uncertainty and the provisional nature of intergovernmental relations. These perceptions are not in tune with the constitutional precepts and their implications, which have guided the development of the Spanish system of decentralized government.

The political culture of Spain has not yet fully assimilated the values which necessarily accompany the co-existence of political institutions led by different parties, or with disparate territorial interests. The interaction between the territorial levels of administration is not without its friction. On occasions, such tensions are used to resolve individual struggles for power or to establish party control. There is, in effect, a certain confusion involving ideology and public policy which clouds Spaniards' perceptions of political life.

In any case, intergovernmental conflict and agreement in Spain are inseparable from a spatial and 'open' distribution of power, provided for in Title VIII of the 1978 Constitution ${ }^{14}$. One must recognize that the ethnoterritorial understanding in Spain will not be free from the tensions and deals which characterize federal or federal-like systems.

(b) The axiom of the politicizing of ethnoterritorial institutions involves the wish, at all three levels of government, to improve political image and prestige both in Spain and abroad. An example is that of 1992, when three major international events were held in Spain: the Olympic Games in Barcelona, Seville's World Fair, and the European Cultural Capital for Madrid. Every level of government directly involved in the organization of these events ran political publicity and marketing campaigns.

The process of European convergence and the growing degree of interdependence in the world economy combine to make the level of institutional politicization more real than symbolic. In this respect, one should underline the European vocation which all governments of the Spanish Autonomous Communities like to claim. This is surely symptomatic of the 'modernization' of ethnoterritorial diversity in Spain after the long stagnation of the Franco era. On a strictly economic level, this process involves a policy to attract foreign investments,

\footnotetext{
${ }^{14}$ Robert Agranoff, "Intergovenmental Politics and Policy: Building Federal Arrangements in Spain", Regional Politics and Policy: An International Journal 4: 1-28.
} 
and facilities for the establishment and growth of new industries, as well as the implementation of regional promotion policies. This is all clearly aimed at making the country or region attractive to investment and development.

Some of the most powerful minority nationalisms in Spain, namely the Basque and Catalan nationalisms, toy with the idea of a Europe in which the central governments of member states, if not the very idea of the nation-state, become gradually less attractive or interesting given the increasing strength of regional governments.

The growing influence of regional elites in their capacity to co-opt and negotiate is also notable. These are legitimized by the constitutional order and are made mostly possible by the budgetary and financial capacities of the governments of the Autonomous Communities. Percentage changes in public expenditure in Spain illustrate this phenomenon explicitly: between 1978 and 1992, central government expenditure dropped from 90 to 65\% of the total, and regional spending rose from nil to $21 \%$. Local spending rose from 10 to $13 \%{ }^{15}$.

\section{Premises: Differential Fact, centralist Inertia}

(c) In the early stages of the decentralization process, the mobilization patterns of the historical nationalities were founded on the premise of the differential fact. This idea is directed towards the Catalan, Galician and Basque cases, notable for their non-Castilian languages, and for their own cultures and specific histories. These last two elements are also common to the other Autonomous Communities. Since then, the constitutional distinction of 1978 between nationalities and regions has been understood and accepted not only by the social, political and economic actors of the Autonomous Communities, but also by the Spain's state-wide political parties.

The expression differential fact is taken to refer to a feature or combination of features which characterize an ethnic group or community with respect to others. It is therefore a concept which derives its meaning from a not easily quantifiable subjective perspective which is rooted in the ethnicity or ethnic identity of a given people. To emphasize the differential fact, the historic nationalities appeal to history, culture, language, origins and traditions, although some of these elements are also vindicated by other Spanish regions.

When the differential fact is seen in terms of politics and of the distribution of power, it displays an asymmetry which is not easy to interpret in the light of the possible future development of the Spanish Estado de las Autonomías. The historical nationalities claimed a legitimate political advantage over the other regions for having had self-governing institutions during the Second Republic. Moreover, Basque and Catalan nationalisms, along with other democratic opposition forces, were especially active during the late Franco years. Later, during the period of democratic transition after the death of the dictator, the leaders of the political groups representing the interests of the Catalan and Basque territories were the only ones who stood for territorial distinctiveness to participate in the various stages of inter-party negotiation.

One would think that the distinct origins of the nationalities could become a reason for them to draw attention to their differences. It seems reasonable to suppose that they would want to maintain their differences with other Autonomous Communities where certain traits are

\footnotetext{
${ }^{15}$ These percentages compare with the figures regarded as 'desirable' for the end of the dentralization process: $50 \%, 25 \%$ and $25 \%$ respectively.
} 
concerned (culture, geography, language, traditions). It remains to be seen whether such a desire is extensible to other fields, in which it is possible for the differential facts (such as economic, institutional or social) to be wielded by almost all the regions of Spain.

(d) The premise of centralist inertia is based on an old perception that the central administration (erroneously identified with the state) has more authority than regional and local levels of government. This conviction is not just the result of a long tradition of authoritarian and dictatorial governments, and in particular of the recent and lasting Francoist dictatorship (1939-75), but of the Jacobin attitude espoused by Spanish liberals throughout the 19th Century. According to their view, state and central government, as well as nation and citizenry, were interchangeable concepts.

During the early stages of the decentralization process, after the referendum which approved the Constitution in 1978, a considerable number of politicians and civil servants were inclined to treat the demands, expectations and needs of Autonomous governments as a passing phenomenon. Some of them, though not openly, tried to discredit the home-rule aspirations of some regions.

The very term state is ambiguously employed in the text of the Constitution. In some Articles $(1,56,137$, and, significantly, in the very title of Title VIII) the intention is for the term to denote the entire organization of the Spanish legal-political system. Thus, the term covers the regional administrations as well as the other agencies and autonomous bodies that make up the state. In other constitutional articles (3.1, 149 and 150), the state is considered synonymous with the institutions of the central administration, together with their peripheral administrations, which may on occasions clash with autonomous administrations.

The Constitutional Court's judgement of July 28th, 1981 clarified the semantic conflict by asserting that the state must be regarded as a composite whole which includes all the institutions of central, regional and local governments. Whatever the case, a certain mentality persists among some politicians and opinion leaders which regards Autonomous and regional institutions as politically dependent on the central administration. This is considerably aggravated by the absence of lateral territorial representation, and especially by the political paralysis of the Senate. The reform of the Upper House, with a view to eliminating serious misunderstandings, is an urgent matter. Centralist inertia, therefore, continues to act as a traditional inhibitor of Spain's spontaneous inclination towards the self-government of the nations and regions that constitute it.

Principles: Democratic Decentralization, Comparative Grievance, Interterritorial Solidarity

(e) The foundations for the principle of democratic decentralization were laid down by Francoism. A unitary concept of Spain had been cunningly imposed through a defense of Spanish nationalism, taken from the totalitarian ideas and values of some of those who had 'won' the Civil War. In the eyes of many of those who had 'lost' the war, all things 'Spanish' adopted an air of cultural genocide, repression and the re-writing of history. Thus, a good many of the forces of democracy and progress were suspicious of the 'Spanish' at the beginning of the democratic transition. During Francoism, and for almost forty years, the 'Spanish' symbology had tried to hide the plural reality of Spain.

The democratic opposition to the Franco regime developed a dense program for the recovery of democratic rights and freedoms, and for the political decentralization of the state. In particular, in the so-called historical nationalities (Catalonia, Basque Country, and Galicia), the 
forces of opposition to Francoism articulated a highly coherent political discourse denouncing the absence of democracy and the constant official attack on their cultural traits. In these communities, demands for democracy and recognized nationhood became analogous. It was in this way that the values of regional autonomy and generalized political decentralization inspired Spanish consciousness to regard them as elements necessary for the recovery of fundamental political freedoms.

If the institutional mechanisms of democratic decentralization have been erratic, it is as a result of the ambiguity of many of the clauses of the Constitution. It is also a consequence of the fact that those who negotiated it and those who wrote it did so in an excessively legalistic style. It is certainly true that the ultimate form of the Estado de las Autonomías could not be precisely predetermined by mere legal parameters. But these deficiencies cannot hide the political feeling that the existence of democracy and freedom in Spain is inexorably linked to the continued protection and survival of power in a decentralized form, and the autonomy of the country's regions.

(f) The principle of comparative grievance determines the mobilization patterns of the nationalities and regions of Spain to a large degree. In accordance with this, the exercise of the right to autonomy legitimately practiced by the regions compels them to claim the same degree of autonomy as the historical nationalities. This is a principle they actively apply to themselves.

Indeed, it is true that most Autonomous Communities were encouraged by the leading parties (principally UCD and PSOE, in the early '80s) to participate in the nascent decentralization process. These parties had taken part in the Pactos Autonómicos of 1981. Once the decentralization process has made substantial headway and entered a more mature stage, there is still the potentially upsetting presence of the three-tiered forces of grievance, levelling and differences, that threaten the system's stability. Leading members of the main Spanish political parties in the '90s (PSOE and PP) insist on a "homogenization of the Autonomies"16 and on the "spreading out of responsibilities"17. Notwithstanding, perceptions like comparative grievance and the differential fact are not easily extensible to positive legislation in that they reflect social realities which are not necessarily quantifiable in financial or institutional terms.

Comparisons may be made from perspectives such as that found in Catalonia, a 'rich' community where the perception of a comparative fiscal grievance has traditionally manifested itself in the form of a strong argument in support of political Catalanism. This perception is based on the idea, shared by a considerable number of Catalans, that their community receives much less from the central administration than their total contribution to the state Treasury. This feeling of financial discrimination has not only been perceived as an obstacle to the later development of Catalonia, but, significantly, it has been traditionally interpreted as the negligence of an inefficient state apparatus which also fails to promote the growth of other less developed regions in Spain. In a country where grudges and envies are inherent features of its character, the zealous desire to not get left behind or be neglected could hardly not play a major role in the development of the most ambitious and innovative

\footnotetext{
${ }^{16}$ 16. Juan Manuel Eguiagaray, "El pacto autonómico", Organización Territorial del Estado (Salamanca, Ediciones Universidad de Salamanca, 1993), p. 99.

17 17. Mariano Rajoy, "Los problemas de la organización territorial del estado después de los acuerdos autonómicos", ibid, p. 48.13
} 
project in contemporary Spanish political history. In this sense, as the Estado de las Autonomías gradually takes shape, the Autonomous Communities keep an eye on each other, and scrutinize, both formally and informally, the transfers and delegations of power which could entail a position of 'privilege' of a given community over the others.

(g) The principle of inter-territorial solidarity is laid down in the 1978 Constitution (Article 2) as fundamentally necessary to guarantee the integration and interrelation of the Spanish nationalities and regions. From a more mundane point of view, the principle refers to the transfer of funds from the richer Autonomous Communities to the poorer, with the aim of attaining a minimal level of basic services state-wide, together with a fair and adequate distribution of the financial burdens.

The Constitution states (Article 40) that the three levels of public power (central, regional and local) must seek to balance out the rates of income, both regional and personal, attending to the modernization and development of all economic sectors, with the ultimate aim of obtaining the same standard of living for all Spaniards (Article 130). It also proposes that the state should guarantee the effective application of the solidarity principle through seeking an economic balance among the regions of Spain (Article 138).

The constitutional solidarity principle and, by extension, the aim to achieve a fairer distribution of resources and economic development across the regions, has suffered a temporary setback, for two basic reasons: (i) the inefficacy of lateral redistribution mechanisms (the Fondo de Compensación Interterritorial, Inter-territorial Compensation Fund), and (ii) the differences in management capacity between regional administrations. This latter case has exposed the competitive aspect of the Estado de las Autonomías and has shed light on the autonomous communities which have proved to be more capable in the management of their rights and responsibilities.

It is unreasonable to expect that income levels will balance out automatically across the regions of Spain as a result of an improved management of the poorer communities and towns, but equally, there is no reason to doubt that this would effectively contribute to a closer convergence. It cannot be argued either that the action of free market forces produces a 'natural' levelling of territorial imbalances. This is a sophistry which has no basis in economic reality. On the other hand, it is often the case that central government intervention in the economy often reflects the interests of regional elites, co-opted at the request of the administration. Only through the concerted action of the central, regional and local administrations will it be possible to maintain adequate levels of inter-territorial solidarity in accordance with the potential of each region's civil society.

Rules: centrifugal Pressure, Ethnoterritorial Mimesis, and Inductive Allocation of powers

(h) The political pressure exercised during the democratic transition by the two most dynamic nationalisms, those of Catalonia and the Basque Country, greatly contributed to the adoption of a constitutional order reflecting the multiethnic nature of Spain. Since then, and during the continuing decentralization process, the rule of centrifugal pressure has been repeatedly and generally applied by ethnoterritorial political elites. It has not only been used as a vehicle for negotiation, but also to dissuade certain politicians and higher civil servants of the central administration from reverting to centralizing tendencies.

The continuous and active presence of Catalan and Basque nationalist party representatives in the Spanish Parliament has been instrumental in the consolidation an autonomist 'vision' of 
the state with respect to the political relations between the three levels of government. What is more, the increasing relative power of regional or federated organizations associated to national coalitions and parties has also decisively contributed the federalization of politics in Spain. The organic federal composition of the Partido Socialista Obrero Español (PSOE, Socialists and Social Democrats) and Izquierda Unida (IU, Communists, Radical Socialists and Independent Leftists), as well as the gradual regionalization of the Partido Popular (PP, Conservatives, Centrists and Christian Democrats), and the electoral success of new regional movements, has reinforced the crucial importance of the spatial element in Spanish politics.

The centrifugal effects of political negotiation on a territorial level in Spain tend to be multiplied by the bilateral relations between central and regional administrations. The practice of bilateralism, combined with comparative grievance, entails major difficulties for the system of the Autonomies, given that the seventeen Autonomous Communities will exert centrifugal pressures of every kind over questions of common interest.

Intergovernmental co-operation of considerable political value has been initiated by sectorial conferences involving the central government and the Autonomous Communities (notably the Fiscal and Financial Policy Commission). Even at the level of consultation, these conferences are vital to the articulation of policies discussed, agreed by consensus, or only partially agreed. The prolonged absence of legislative requirements which systematize federal practices in Spain could in the long run get in the way of the consolidation of the Spanish Estado de las Autonomías.

(i) Nationalities and regions are constitutive units of the Spanish state. However, there is a clear asymmetry where the legitimacy of their political claims is concerned. While the historical nationalities were the first to take the constitutional initiative to attract resources and powers since the early days of the decentralization process, the other regions have followed suit by imitating Catalonia, the Basque Country and Galicia. According to the rule of ethnoterritorial mimesis, from the very beginning, the historical nationalities aspired to rights and powers comparable to those of central government: exclusive powers, their own police force, external signs and ornamental emblems, official visits to foreign places, self-governing rights established by regional parliaments, public policies in the fields of health, education and social security, and so on. Subsequently, the more ambitious regions wanted the same powers as the nationalities (such as Andalusia in 1981, followed by Valencia and the Canary Islands). Finally, these same communities became models for parts of Spain with less well-defined ethnoterritorial identities ${ }^{18}$. From the perspective of administrative organization, the Autonomous Communities have chosen to reproduce the state to scale instead of reducing the state apparatus, both at the central and regional levels. For this reason, a large number of the criticisms directed towards the persistence of a costly and inefficient regional replication of the central administration, could be extended to public agencies of the Autonomies, and in particular to the relations between these institutions and local councils.

In line with the concept of ethnoterritorial mimesis, it could be argued that Basque nationalism, especially in its most separatist forms, has played with the idea of setting up an independent state for the Basque Country. Given the peculiar confederation of its historical

\footnotetext{
${ }^{18}$ Certain areas lacking in self-governing experience suddenly professed aspirations to autonomy. Cantabria, La Rioja and the province of Madrid became uniprovincial autonomies although they had never had a tradition of self-government.
} 
territories, such a state would be paradoxically structured very much like the Spanish plurinational state. Modern political Catalanism, for its part, wants an independent fiscal system rather like the quota mechanisms currently operating in the Basque Country, if not simply a greater degree of financial autonomy. Galicia would probably follow Catalonia in having powers transferred from central state institutions. It should be noted, however, that the mechanicity of the mimetic process would remain relative to the extent to which citizens of the Basque Country identified themselves as 'Spanish', at least to some significant degree, and that Catalanism maintained its tradition of a nationalism which seeks to reform Spain as well as Catalonia. The strength of radical nationalism in Galicia does not seem to indicate anything like the collapse of a nationalism which is firmly rooted in a wish to belong to Spain as a whole.

(j) The rule of the inductive allocation of powers sets the pace of the construction of Spain's Estado de las Autonomías. This rule, which is implicit in the provisions of Title VIII of the 1978 Constitution, draws attention to the fact that the division of powers between the three territorial levels of the administration is a matter yet to be completed. Essentially, the Spanish decentralization process has followed an open model of territorial structuring which only the passage of time has gradually defined, as it shall continue to do.

The constitutional simplicity of Title VIII allows for great flexibility of interpretation where the possibility of self-government is concerned. It depends on the political will of each nationality or region. Furthermore, the constitutional adoption of a device which marked out the allocation of specific powers for the Autonomous Communities and the required procedure for their adoption, without establishing a clear separation of rights and powers, was the only feasible way to initiate a political decentralization process. It must be remembered that during the transition to democracy this was the thorniest issue, and therefore required complete consensus.

The degree of heterogeneity among the seventeen Autonomous Communities has levelled over time, although the decentralization process is far from over. In contrast to the traditional philosophy upon which federal states such as Germany, Australia, the USA or Switzerland have been modelled and built, the decentralization process in Spain can only be regarded as complete once a period of intergovernmental familiarity has elapsed. At the same time, the process of European convergence will exercise considerable influence in the 'final' distribution of regional powers and responsibilities.

\section{Conclusion}

In the immediate future, inter-governmental relations will become decisive of the success or failure of the Estado de las Autonomías and the ongoing federalization of the institutional practices. These relations will condition the inescapably experimental 16 nature of shared powers and responsibilities. It is indeed the case that the administrative and political processes will be more laborious than those hierarchically determined in unitary centralized states. But they will enjoy a greater degree of legitimacy as well as greater effectiveness.

In Spain, as in the rest of the countries of its socio-economic environment, political complexity cannot become synonymous with inefficiency ${ }^{19}$. Political results are not reducible either to

\footnotetext{
${ }^{19}$ John Kincaid, "Values and Value Transfers in Federalism", Publius: The Journal of Federalism 25 (Spring 1995): 41-43.
} 
quantifiable products. In the context of ethnoterritorial accommodation of plural countries like Spain, the shortest route is not always a straight line. In complex decision-making processes the temptation towards simplification often ends up in misunderstanding.

The weaknesses of a multilateral debate between nationalities, regions and central government, and, in particular, the atrophy of the Senate as a territorially based House, constitute a dangerous invitation to the dismantling of the autonomous regional web. A renewed cross-party consensus is required, to ensure a constitutional adaptation to the federalization of a heterogeneous reality. Such an agreement would have to precede its legal formalization. Constitutional engineering is in itself sterile and inconsequential. In Spain the tradition of laying down agreements which have no basis in reality has been an obstacle to the consolidation of democratic values. The greediness of the centre towards the periphery may have been the most evident of the misguided tendencies of the country's political modernization.

In Spain, the absence of an enlightened and authoritative elite, and of a centralizing political leadership, has gone hand in hand with a constant affirmation of ethnoterritorial diversity. The federalization of the Estado de las Autonomías must not be confused with the unfolding of more or less sophisticated constitutional governing techniques. It is largely a matter of finding a political place for the vitality of its constituent units, and of institutionalizing the free and natural understanding which its citizens and peoples engage in daily.

The territorialization of politics has manifested itself in the proliferation of regionally based parties. Internal asymmetries in Spain have also expressed themselves in a wide and varied mosaic of political parties. This is not a hindrance for parties with countrywide aspirations. But even the political organizations receiving state-wide public support have structured themselves in line with the federal texture of Spain.

At this moment in history, the pillars of civic culture in Spain appear to point to a tendency towards agreement and for the toleration of dissent. The weight of past civil confrontations is still considerable. The effects of political violence in the Basque Country continues to be the negative referent in the generally peaceful cohabitation of the Spanish regions and peoples.

The values that matter most in democratic life are precisely those which favor agreement and understanding, and which reject intolerance. Beyond party interests, Spaniards are committed to paving the way towards a common future placed somewhere between the possible, the probable and the desirable. The ultimate challenge for Spain lies in finding the right way of living with its unity and diversity simultaneously. Its political future depends on it. 